Supporting Information for

\title{
Macrocephatriolides A and B, Two Guaianolide Trimers from Ainsliaea macrocephala as PTP1B Inhibitors and Insulin Sensitizers
}

Yong-Mei Ren a, b, c\#, Rui Zhang ${ }^{\text {a\# }}$, Zheling Feng ${ }^{\mathrm{d}}$, Chang-Qiang Ke ${ }^{\mathrm{a}}$, Sheng Yao ${ }^{\mathrm{a}}$, Chunping Tang ${ }^{\mathrm{a}}$, Ligen Lin ${ }^{\mathrm{d}}$, and Yang Ye $\mathrm{e}^{\mathrm{a}, \mathrm{b}, \mathrm{c}^{*}}$

${ }^{a}$ State Key Laboratory of Drug Research and Natural Products Chemistry Department,

Shanghai Institute of Materia Medica, Chinese Academy of Sciences, Shanghai 201203,

People's Republic of China

${ }^{b}$ University of Chinese Academy of Sciences, Beijing 100049, People's Republic of China;

${ }^{c}$ School of Life Science and Technology, ShanghaiTech University, Shanghai 201203,

People's Republic of China

${ }^{d}$ State Key Laboratory of Quality Research in Chinese Medicine, Institute of Chinese Medical Sciences, University of Macau, Avenida da Universidade, Taipa, Macau 999078, China

*Email: yye@simm.ac.cn

$\# Y-M . R$. and R. Z. contributed equally to this paper 


\section{Table of Contents}

Chart S1. Sesquiterpene oligomers from the Ainsliaea genus.................................S3

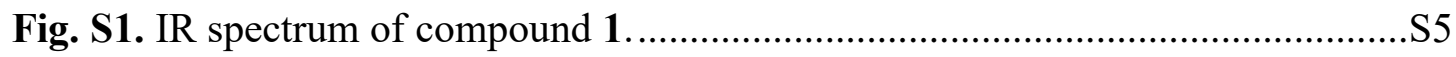

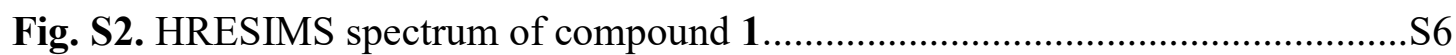

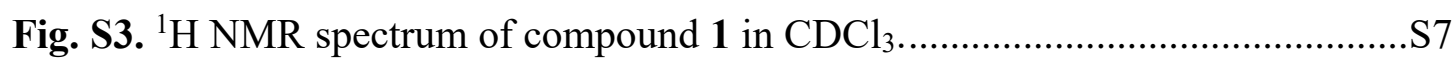

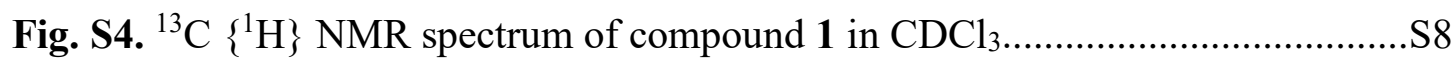

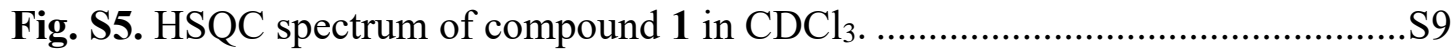

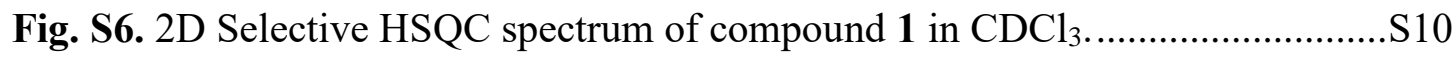

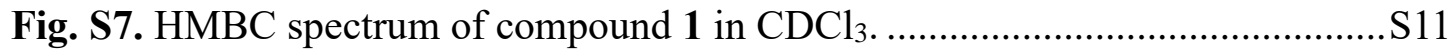

Fig. S8. 2D Selective HMBC spectrum of compound 1 in $\mathrm{CDCl}_{3} \ldots \ldots \ldots \ldots \ldots \ldots \ldots . . . . . . . . . . . . . .212$

Fig. S9. 2D Selective HMBC spectrum of compound 1 in $\mathrm{CDCl}_{3} \ldots \ldots \ldots \ldots \ldots \ldots \ldots . . . . . . . . . . . . .313$

Fig. S10. 2D Selective HMBC spectrum of compound 1 in $\mathrm{CDCl}_{3} \ldots \ldots \ldots \ldots \ldots \ldots \ldots \ldots . . . . . . . . . . .14$

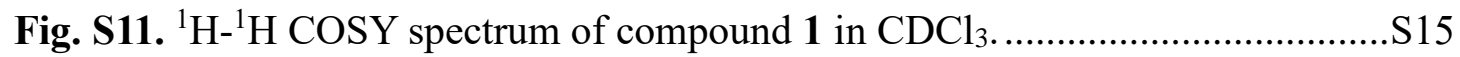

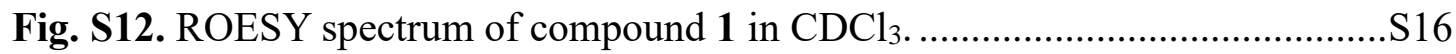

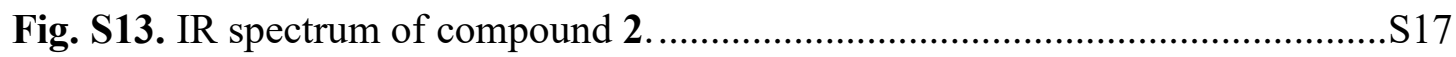

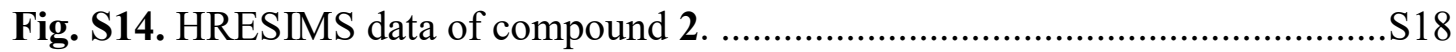

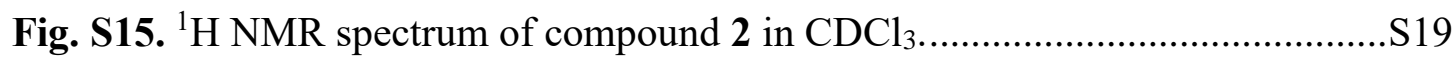

Fig. S16. 1DTOCSY (4.389 PPM) spectrum of compound 2 in $\mathrm{CDCl}_{3} \ldots \ldots \ldots \ldots \ldots \ldots . . . \mathrm{S} 20$

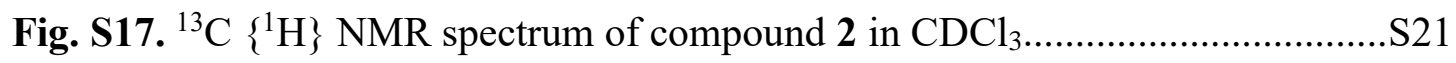

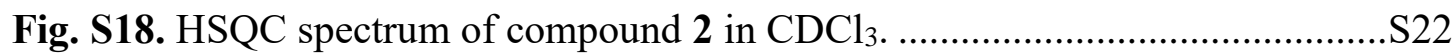

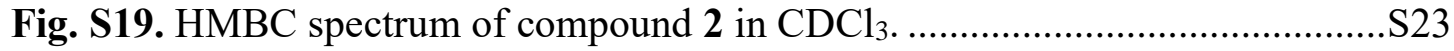

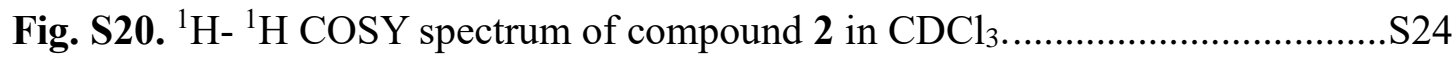

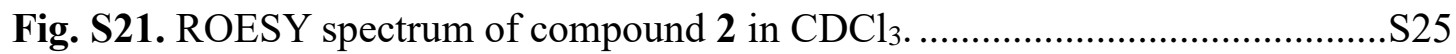

Experimental details for TDDFT ECD calculations ............................................S26

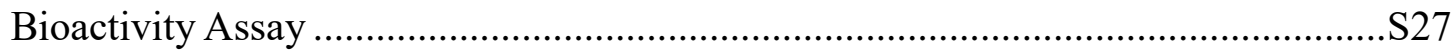


Chart S1. Sesquiterpene oligomers from the Ainsliaea genus.

Type A linkage

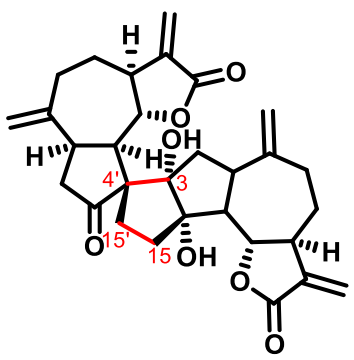

Ainsliadimer A

\section{Type B linkage}

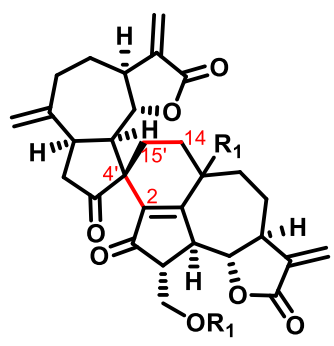

Ainsliadimer $\mathbf{B} \quad \mathbf{R}_{1}=\beta$-OH $\quad \mathbf{R}_{2}=\mathbf{H}$ Ainsliadimer $\mathbf{D} \quad \mathbf{R}_{1}=\alpha-\mathrm{OH} \quad \mathbf{R}_{\mathbf{2}}=\mathbf{H}$ Ainsliadimer $\mathbf{G} \quad \mathbf{R}_{1}=\alpha-\mathrm{OH} \quad \mathbf{R}_{\mathbf{2}}=\mathbf{M e}$ Ainsliadimer $\mathbf{H} \quad \mathbf{R}_{1}=\alpha-\mathrm{OH} \quad \mathbf{R}_{\mathbf{2}}=\mathrm{Et}$

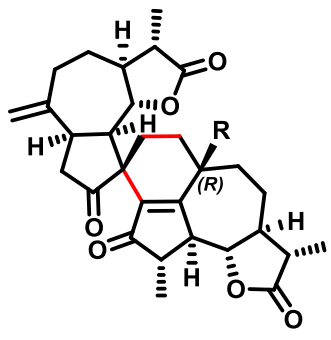

Ainsliadimer $\mathbf{C} \quad \mathbf{R}=\alpha-\mathrm{OH}$ Ainsliadimer $\mathbf{F} \mathbf{R}=\beta$-OH

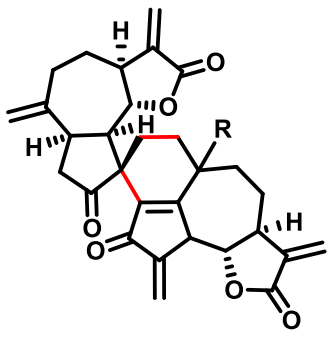

Gochnatiolide A $\mathbf{R}=\alpha-\mathrm{OH}$ Gochnatiolide B $\mathbf{R}=\beta-\mathrm{OH}$ Gochnatiolide C $\mathbf{R}=\alpha-\mathrm{H}$ Ainsliadimer $\mathbf{E} \mathbf{R}=\beta-\mathbf{H}$

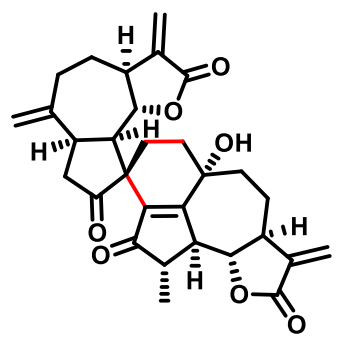

Ainsliadimer I

Type C linkage

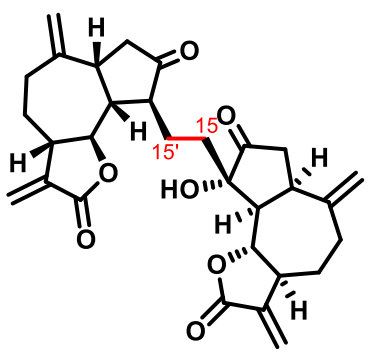

Ainsliadimer $\mathbf{J}$

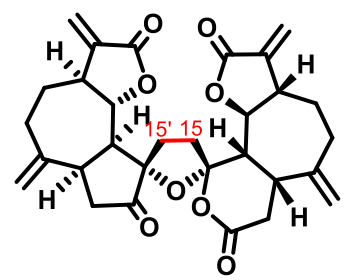

Macrocephadiolide A

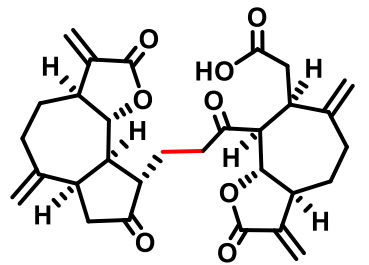

Macrocephadiolide B 
Type B + Type B

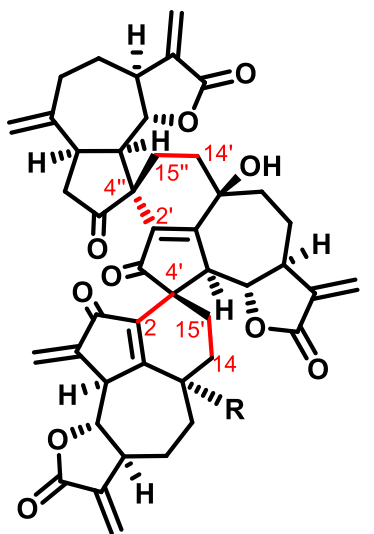

Ainsliatrimer A $\mathrm{R}=\mathrm{H}$

Ainsliatrimer $B \quad \mathrm{R}=\mathrm{OH}$

Type B + Type C

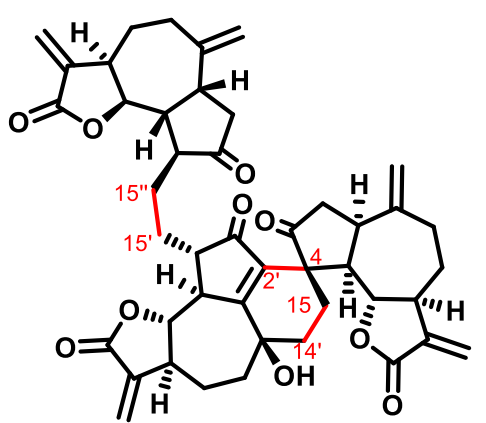

Ainsliatriolide A

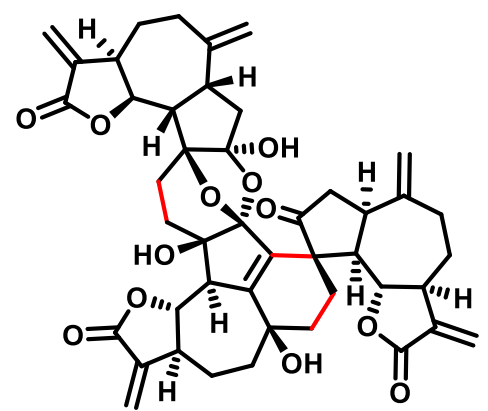

Ainsliatriolide B

Type B + Type D + Type C

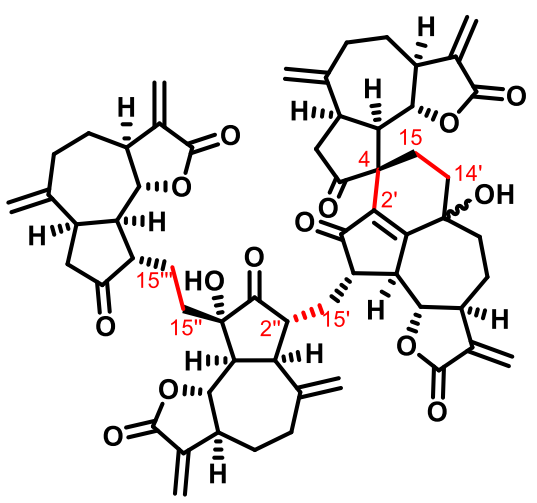

Ainsliatetramer A 10' $S$ Ainsliatetramer B $10^{\prime} R$ 


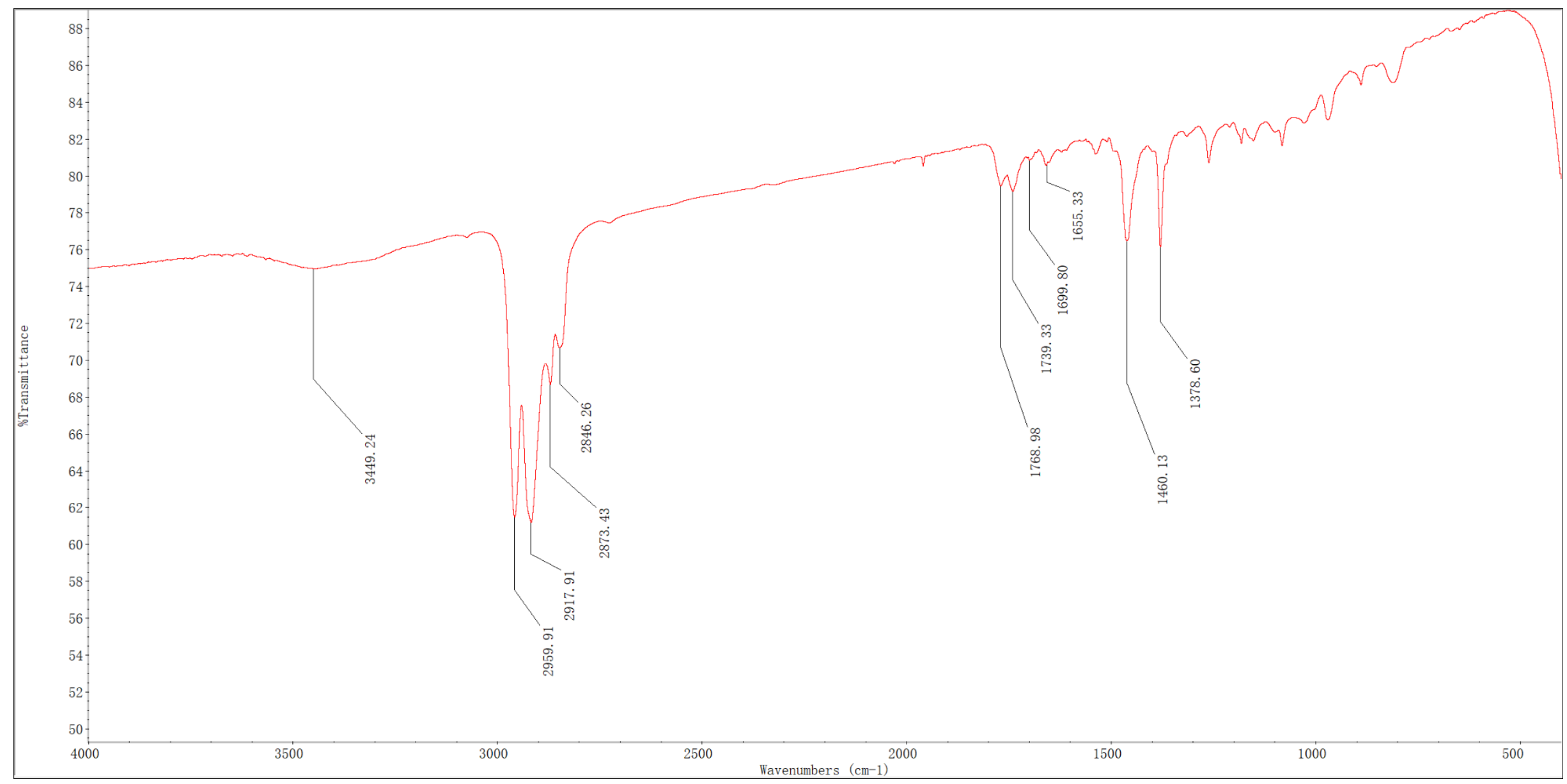

Fig. S1. IR spectrum of compound $\mathbf{1}$. 


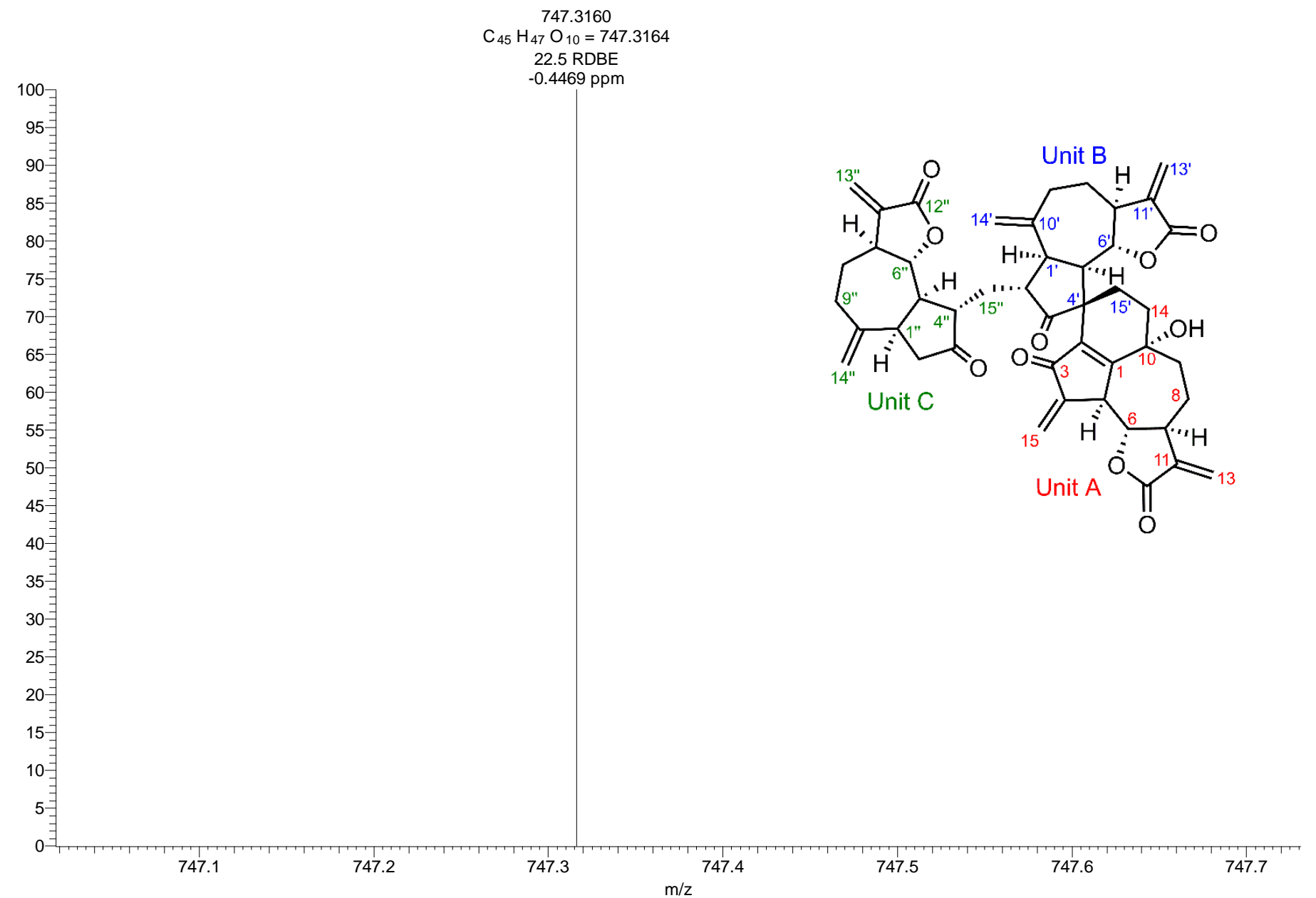

Fig. S2. HRESIMS spectrum of compound 1. 


\section{ᄀ

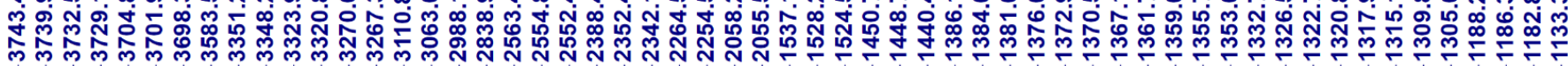
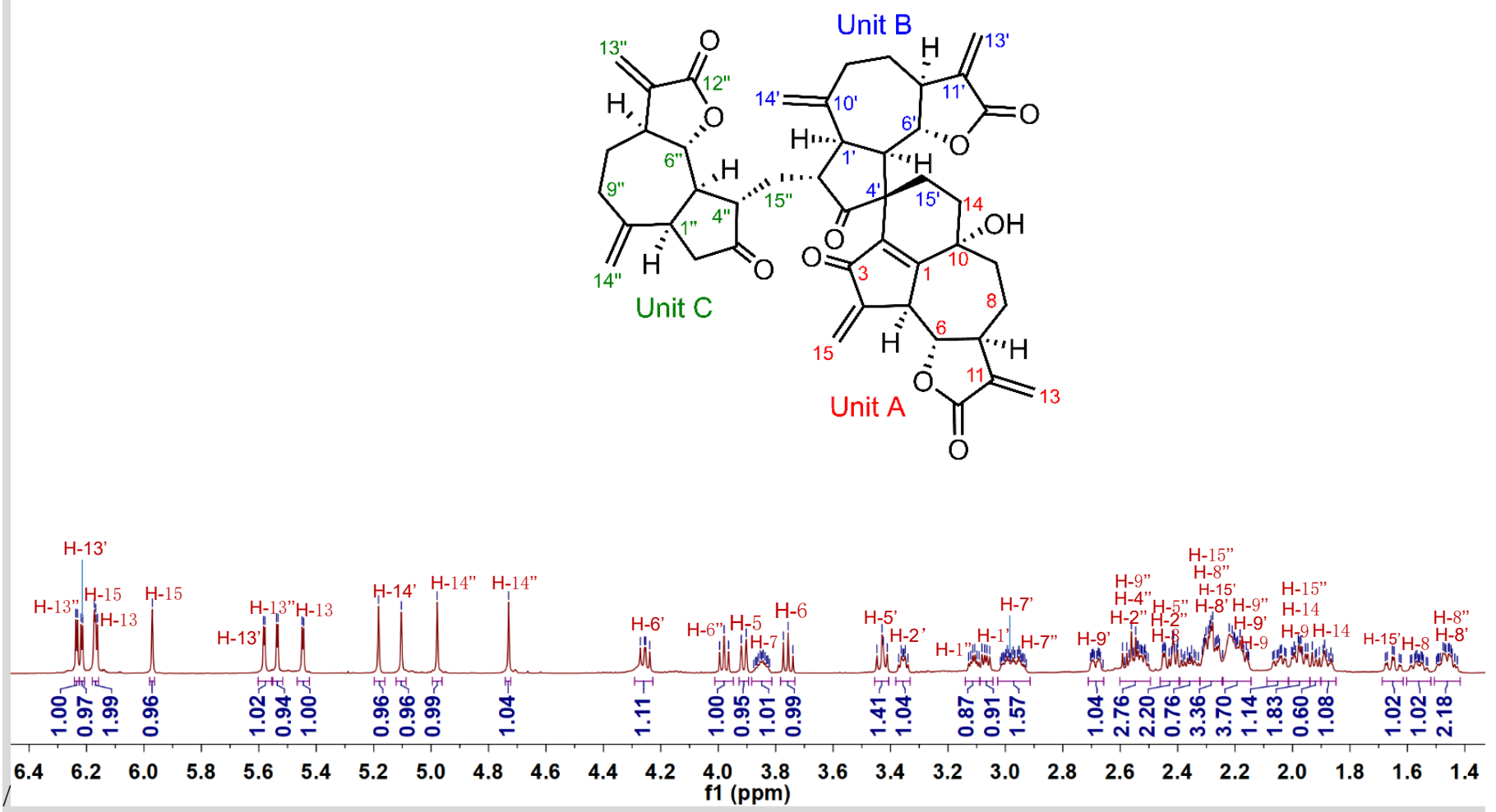

Fig. S3. ${ }^{1} \mathrm{H}$ NMR spectrum of compound $\mathbf{1}$ in $\mathrm{CDCl}_{3}(600 \mathrm{MHz})$. 

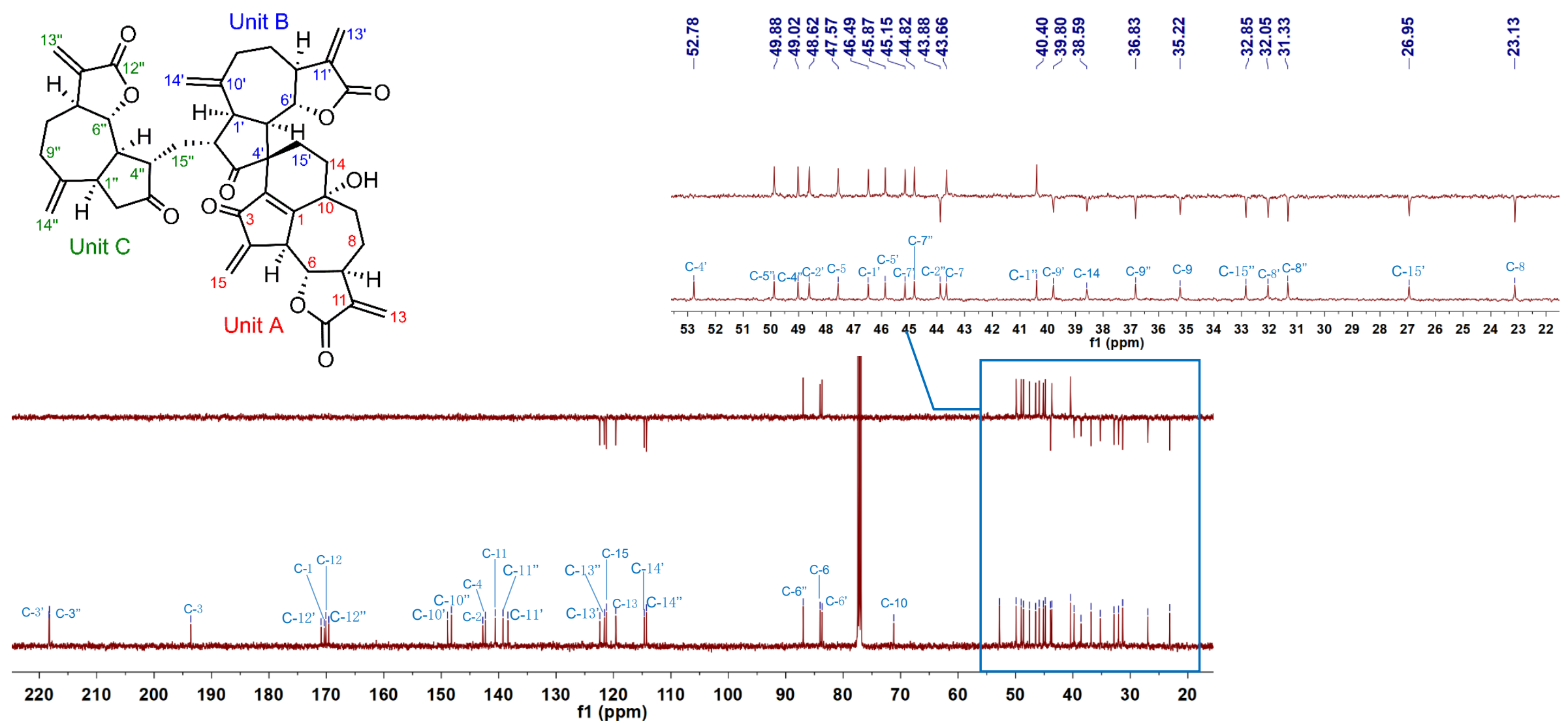

Fig. S4. ${ }^{13} \mathrm{C}\left\{{ }^{1} \mathrm{H}\right\}$ NMR spectrum of compound $\mathbf{1}$ in $\mathrm{CDCl}_{3}(125 \mathrm{MHz})$. 


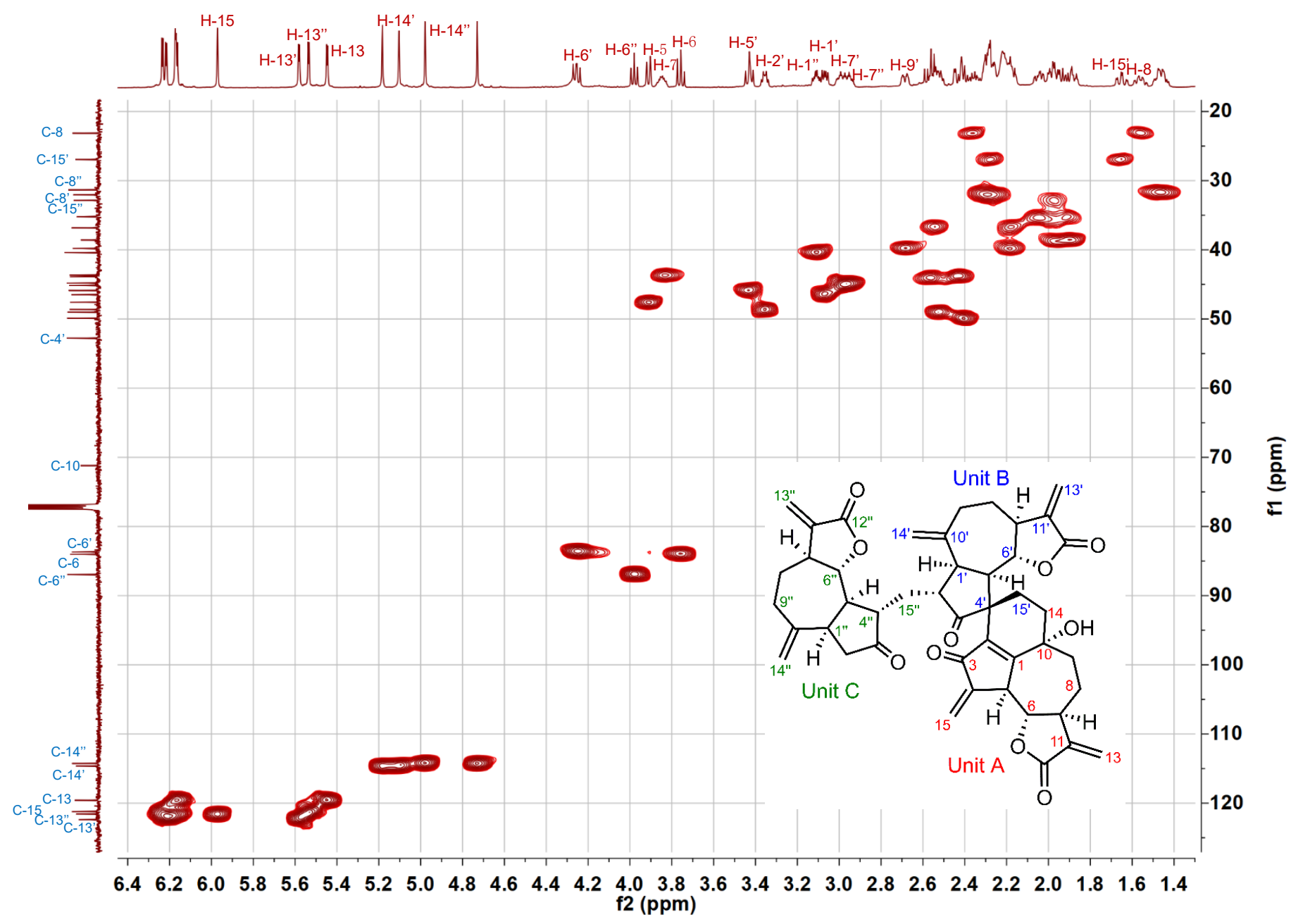

Fig. S5. HSQC spectrum of compound 1 in $\mathrm{CDCl}_{3}(500 \mathrm{MHz})$.

Sq 

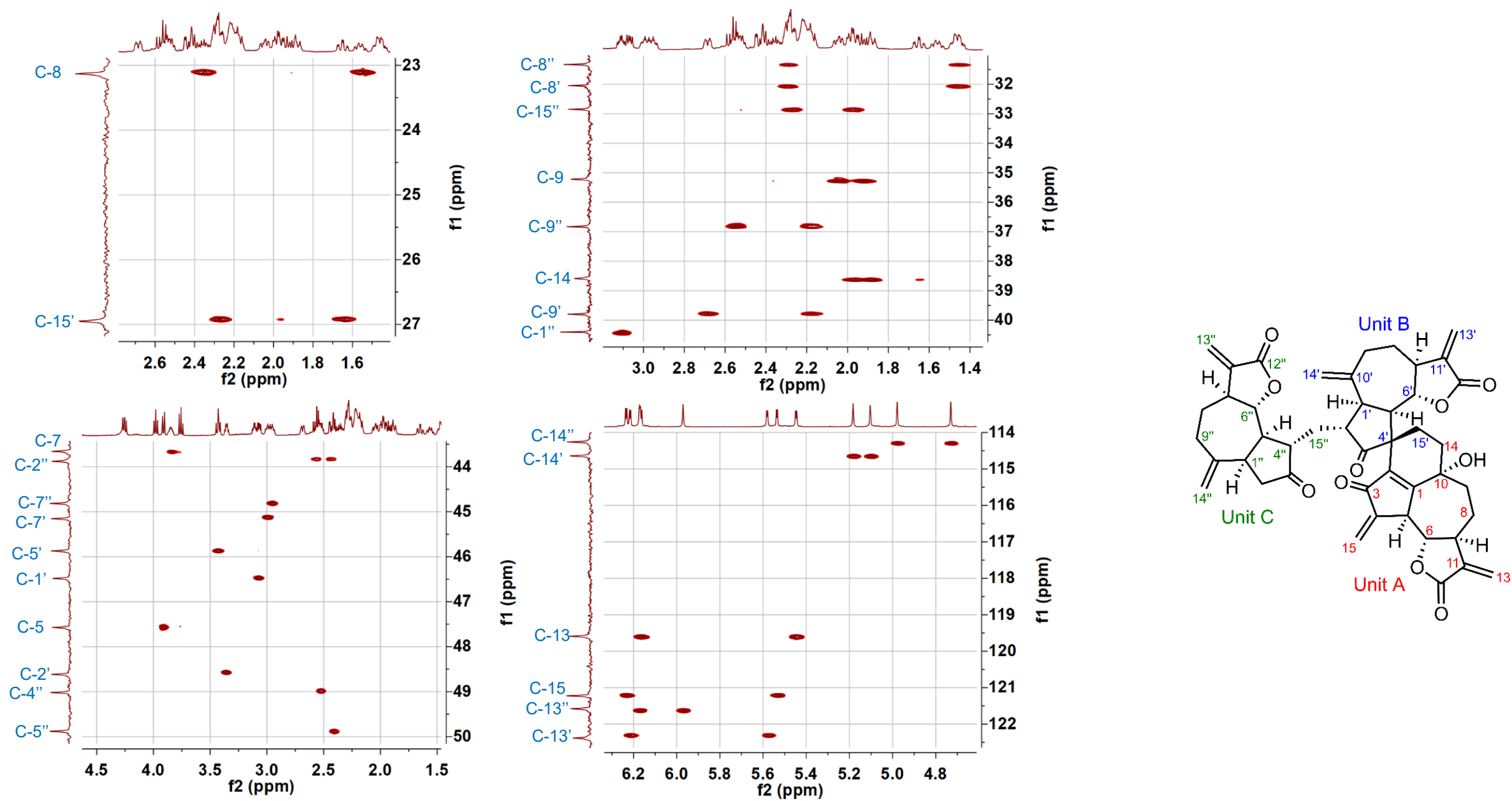

Fig. S6. 2D Selective HSQC spectrum of compound 1 in $\mathrm{CDCl}_{3}(500 \mathrm{MHz})$. 


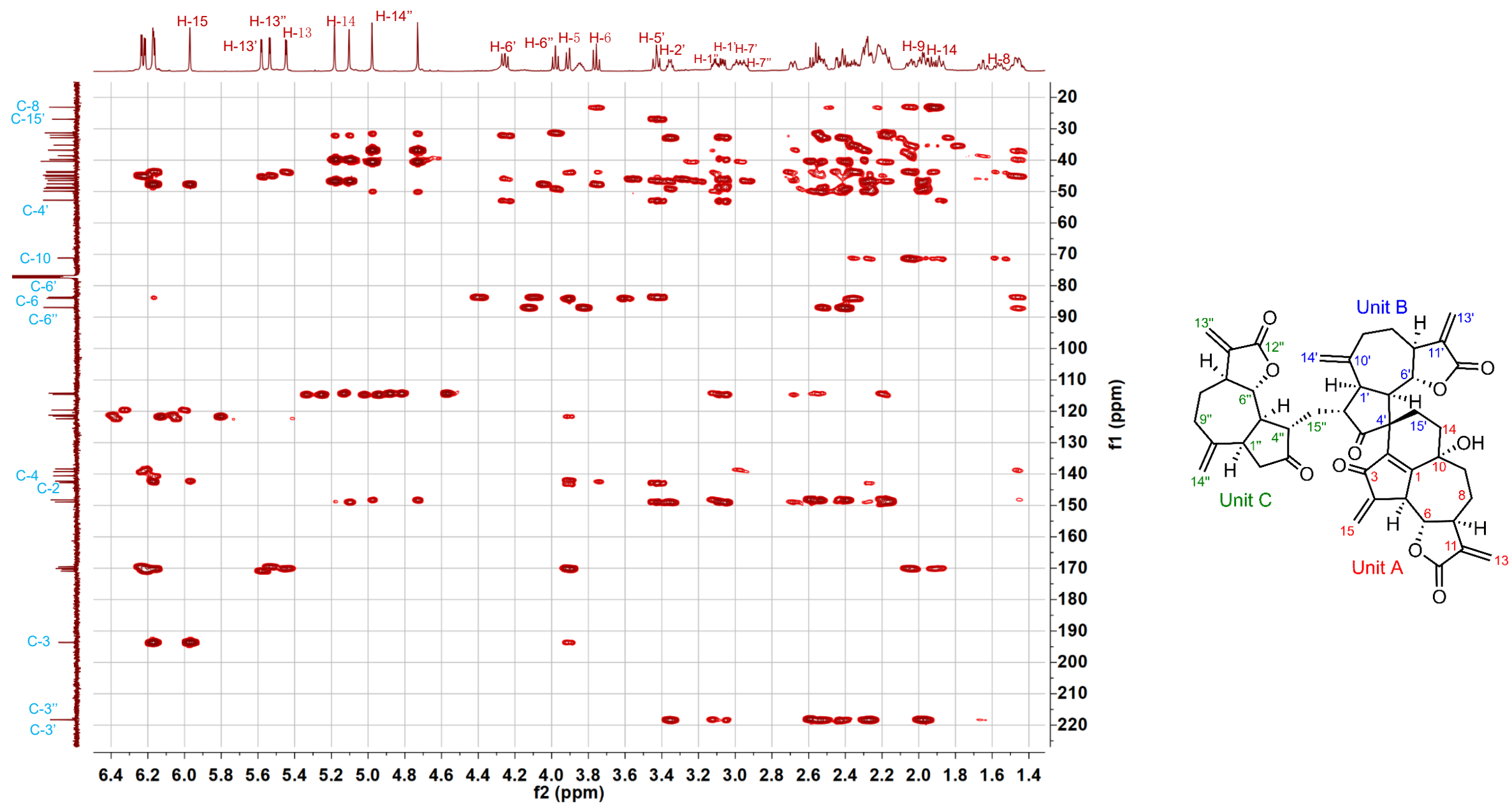

Fig. S7. HMBC spectrum of compound 1 in $\mathrm{CDCl}_{3}(500 \mathrm{MHz})$. 

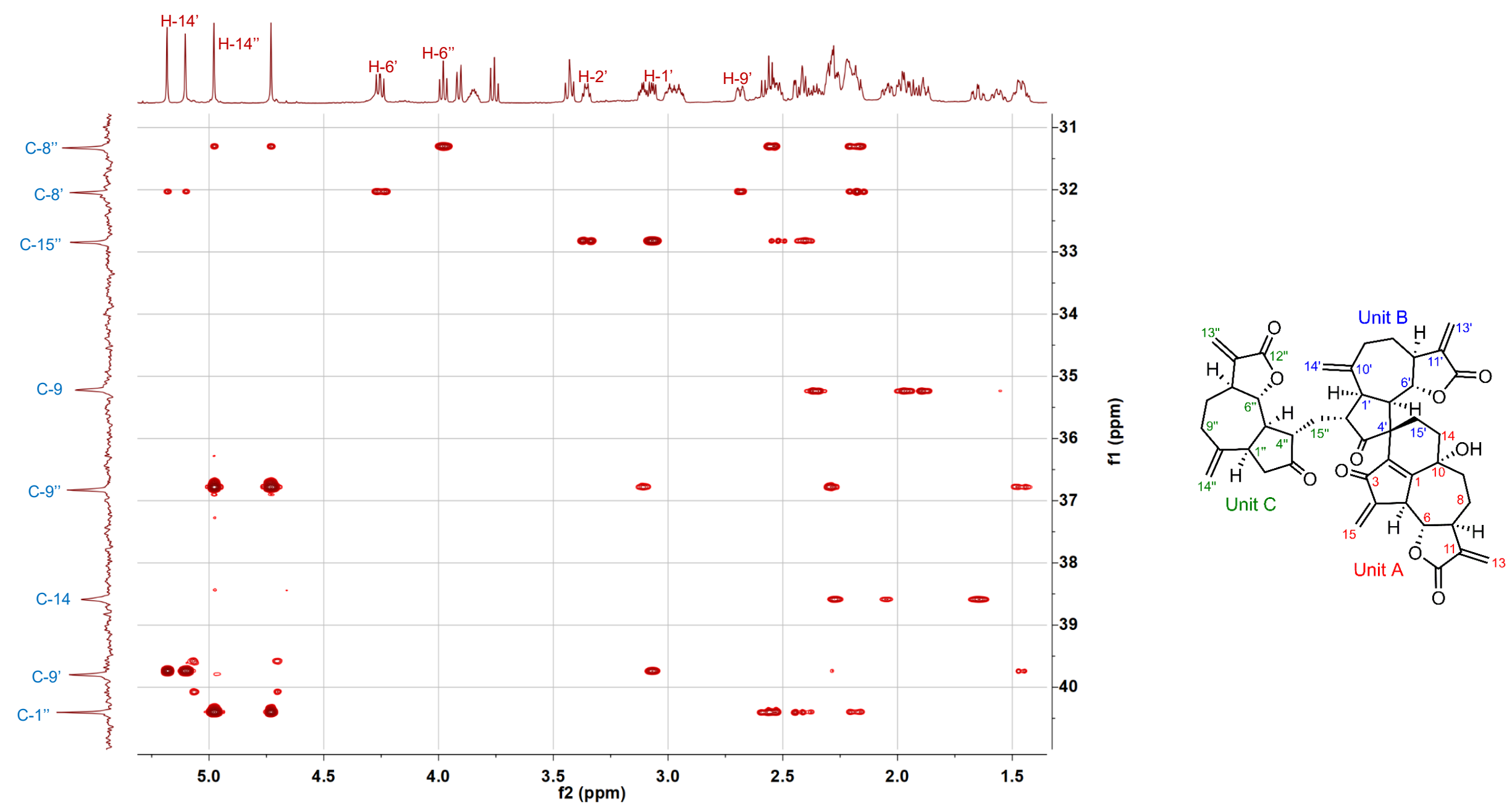

Fig. S8. 2D Selective HMBC spectrum of compound 1 in $\mathrm{CDCl}_{3}(500 \mathrm{MHz})$. 


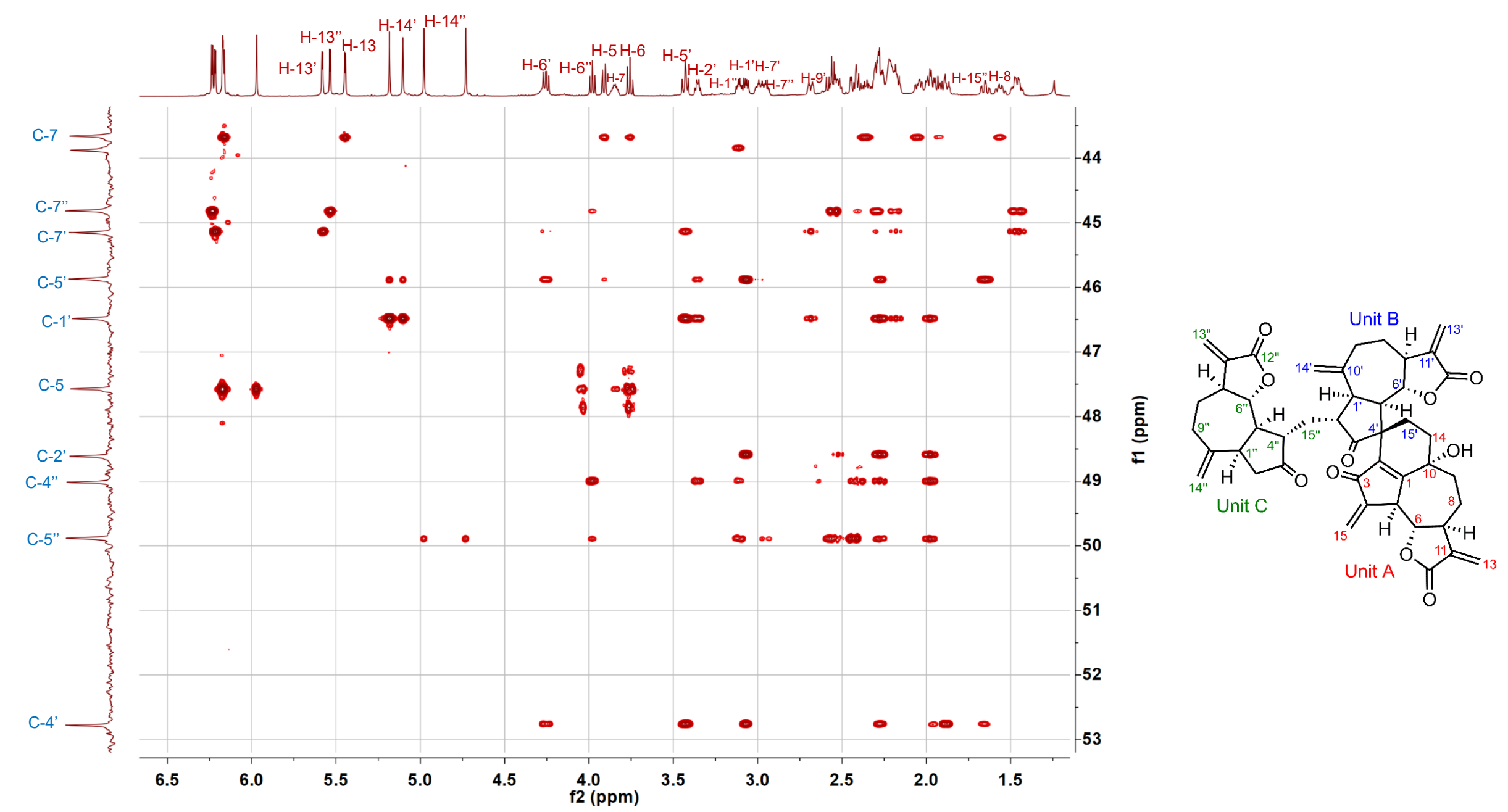

Fig. S9. 2D Selective $\mathrm{HMBC}$ spectrum of compound 1 in $\mathrm{CDCl}_{3}(500 \mathrm{MHz})$. 

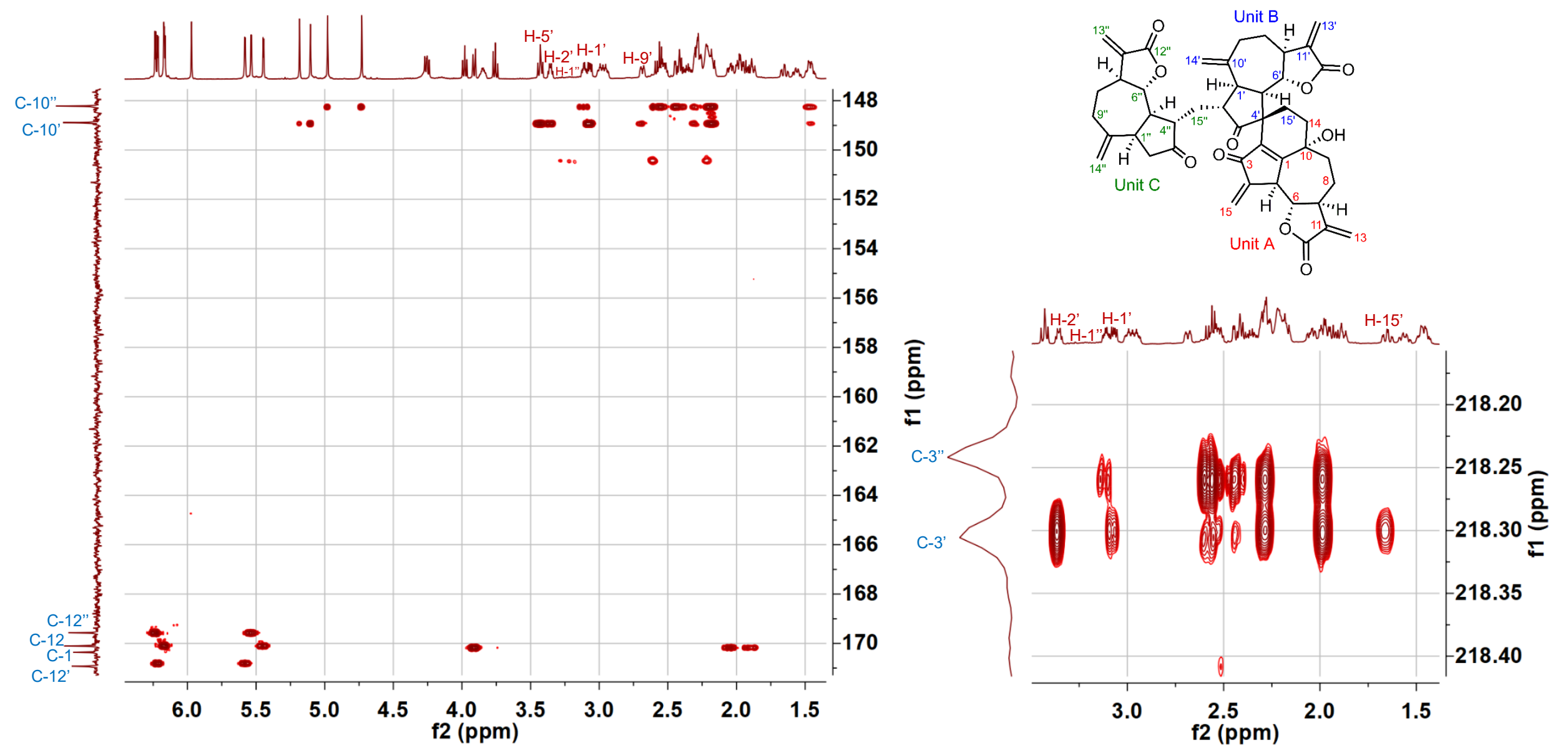

Fig. S10. 2D Selective HMBC spectrum of compound 1 in $\mathrm{CDCl}_{3}(500 \mathrm{MHz})$. 

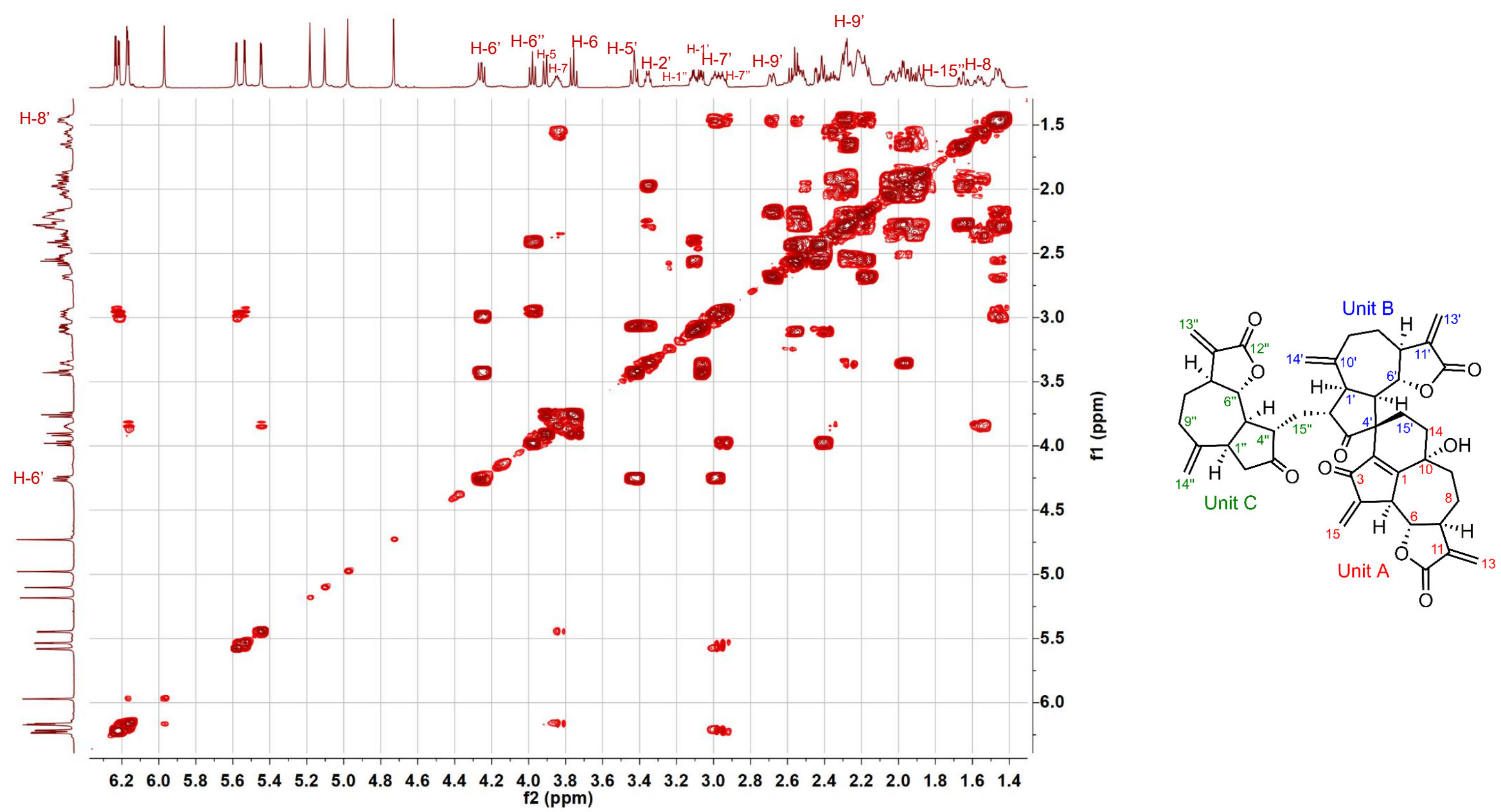

Fig. S11. ${ }^{1} \mathrm{H}-{ }^{1} \mathrm{H}$ COSY spectrum of compound 1 in $\mathrm{CDCl}_{3}(600 \mathrm{MHz})$. 


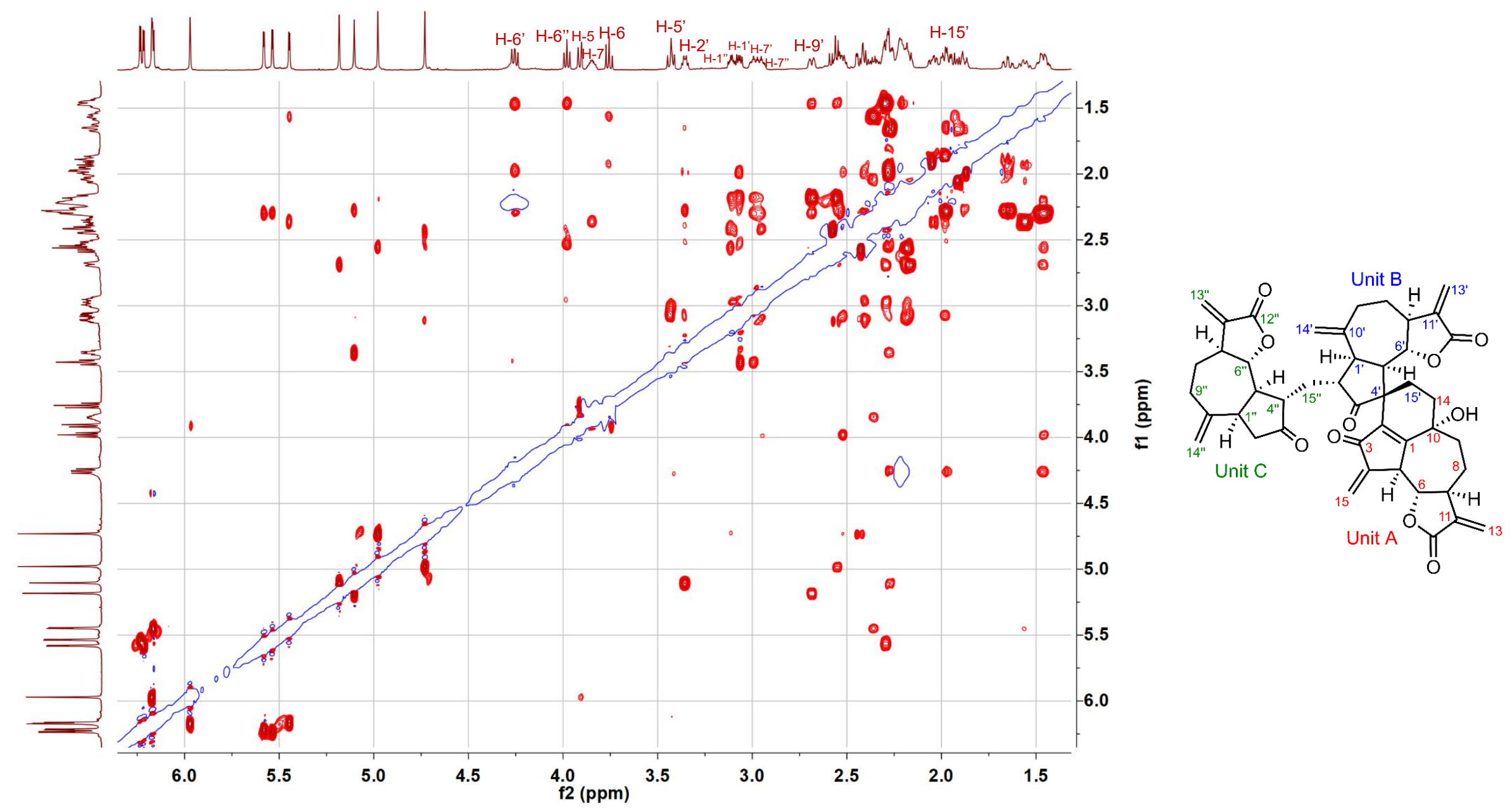

Fig. S12. ROESY spectrum of compound 1 in $\mathrm{CDCl}_{3}(600 \mathrm{MHz})$. 


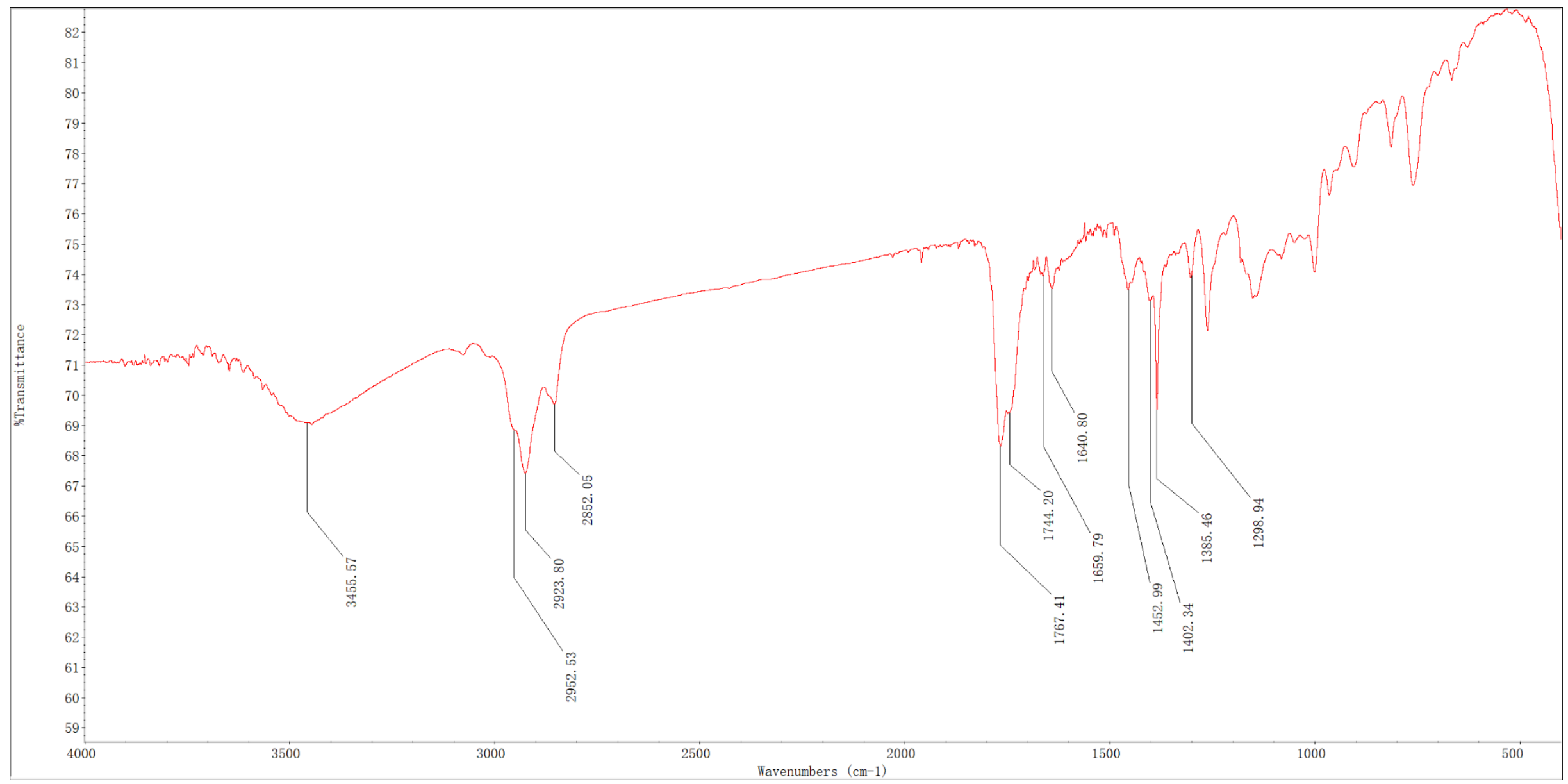

Fig. S13. IR spectrum of compound 2. 


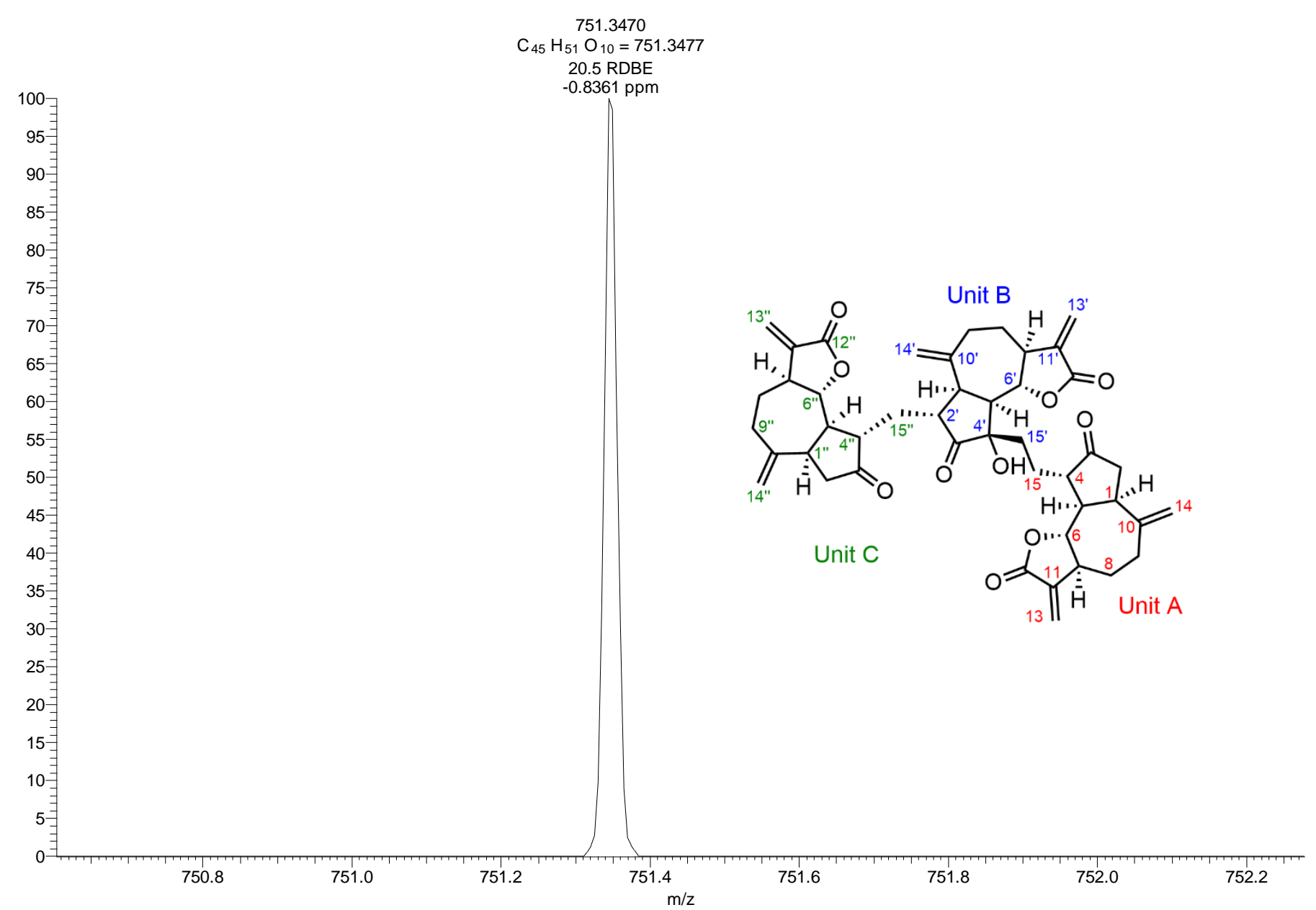

Fig. S14. HRESIMS data of compound 2. 

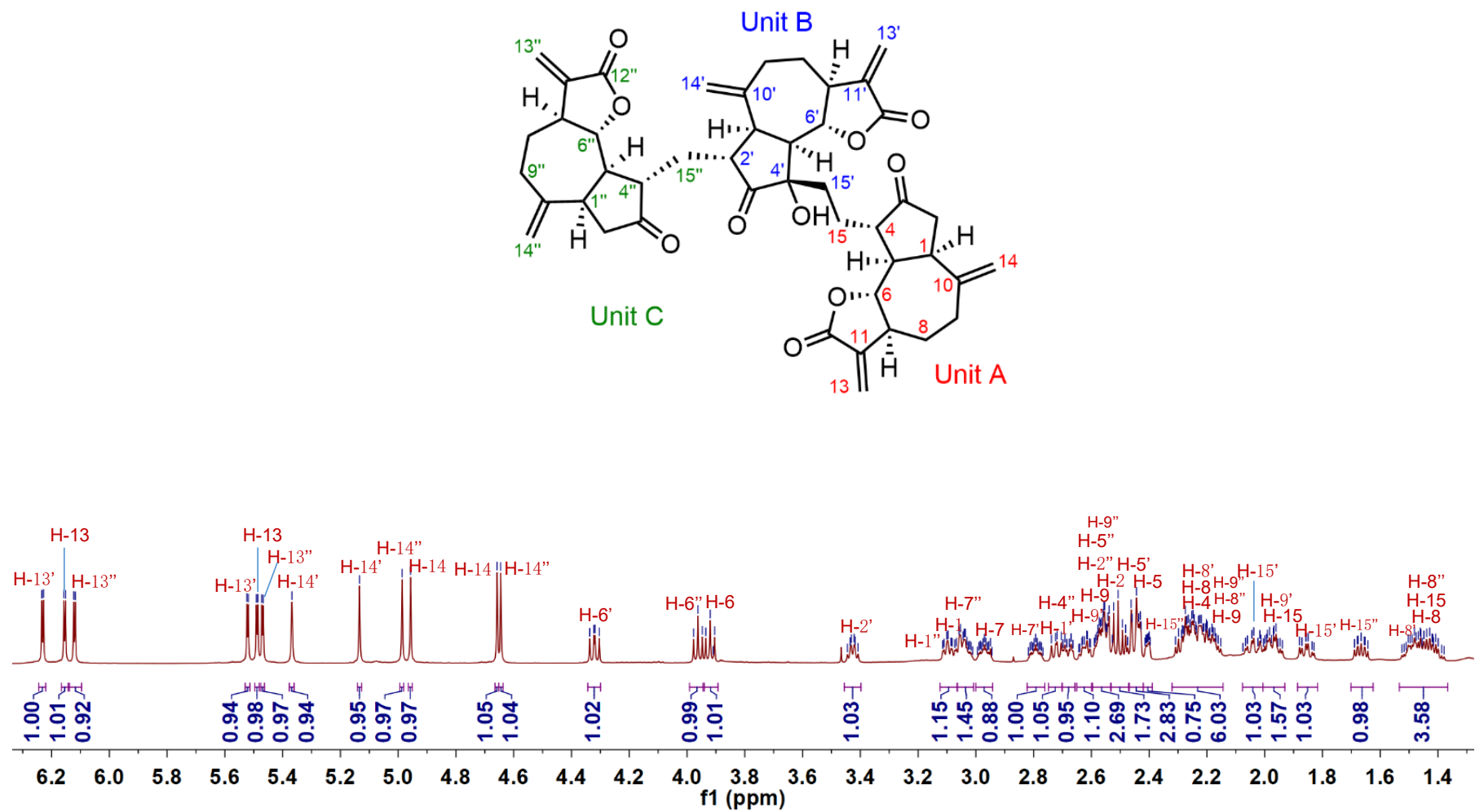

Fig. S15. ${ }^{1} \mathrm{H}$ NMR spectrum of compound 2 in $\mathrm{CDCl}_{3}(600 \mathrm{MHz})$. 


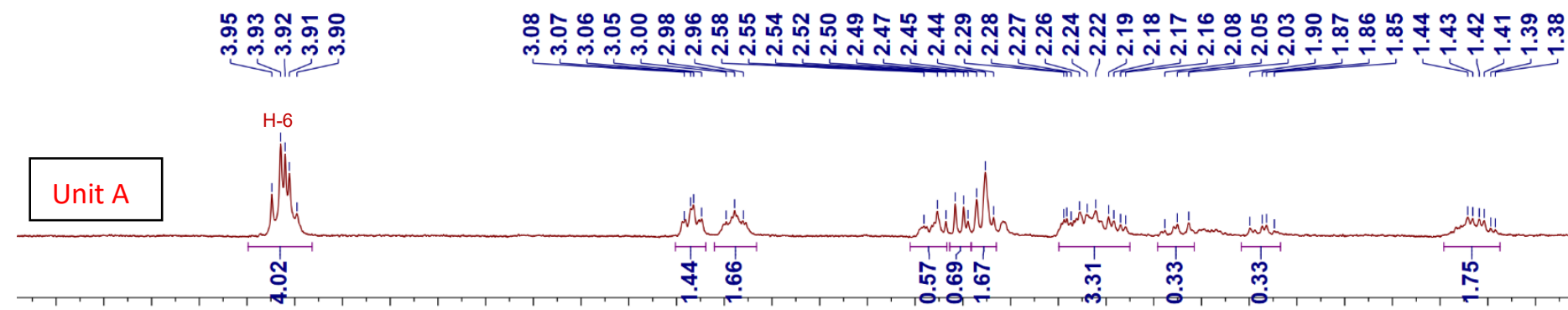

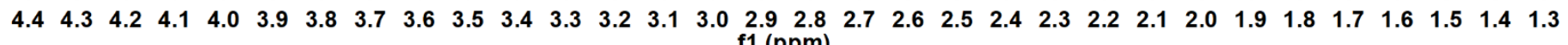

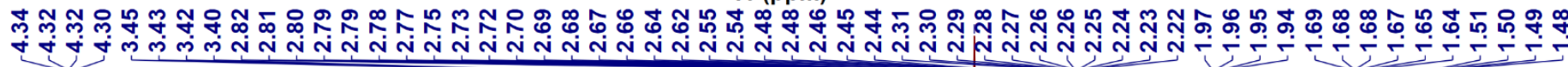

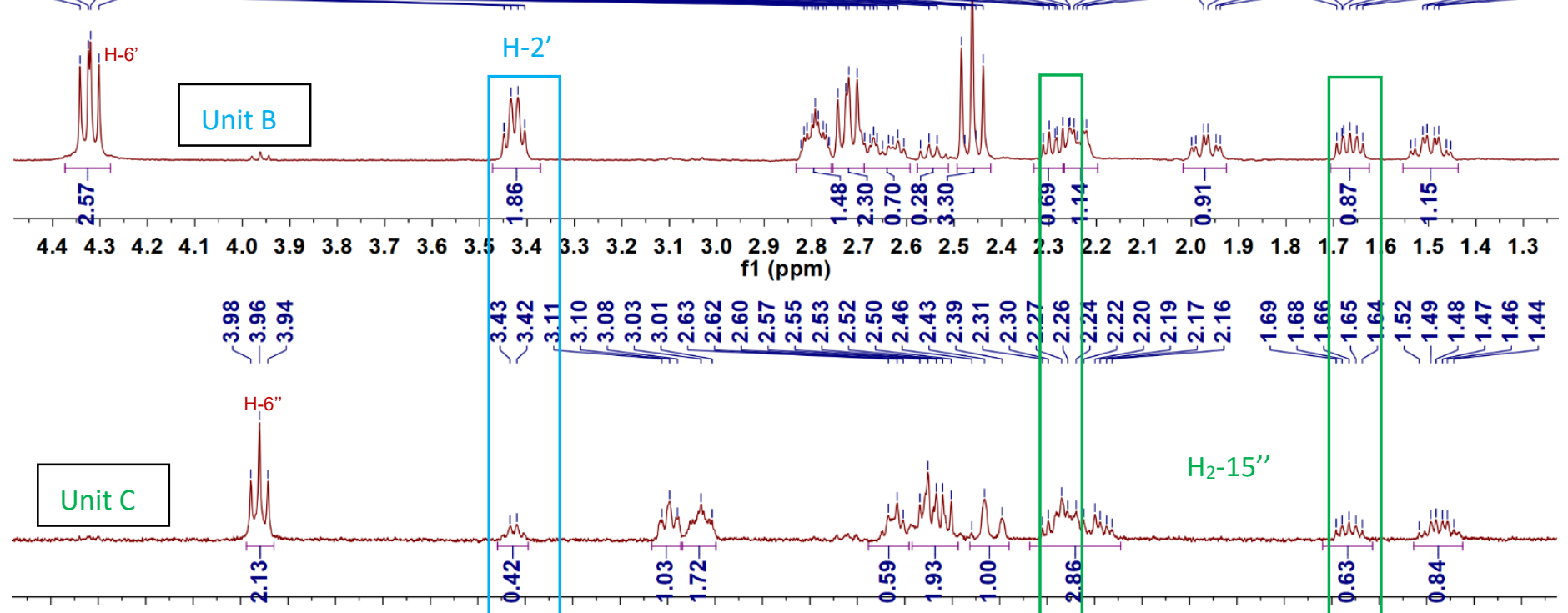

\begin{tabular}{lllllllllll|lllllllllllllllllllllll}
4.4 & 4.3 & 4.2 & 4.1 & 4.0 & 3.9 & 3.8 & 3.7 & 3.6 & 3.5 & 3.4 & 3.3 & 3.2 & 3.1 & 3.0 & 2.9 & 2.8 & 2.7 & 2.6 & 2.5 & 2.4 & 2.3 & 2.2 & 2.1 & 2.0 & 1.9 & 1.8 & 1.7 & 1.6 & 1.5 & 1.4 & 1.3
\end{tabular}

Fig. S16. 1DTOCSY (4.389 PPM) spectrum of compound 2 in $\mathrm{CDCl}_{3}(500 \mathrm{MHz})$. 


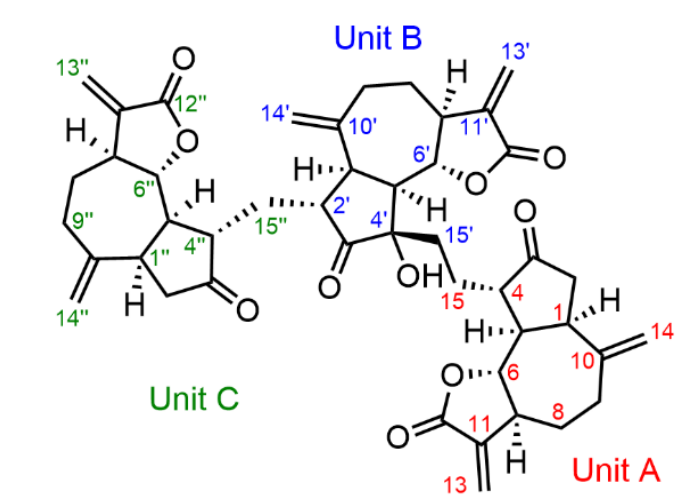

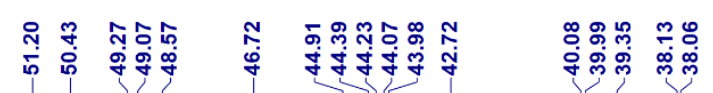

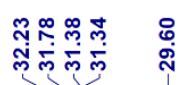

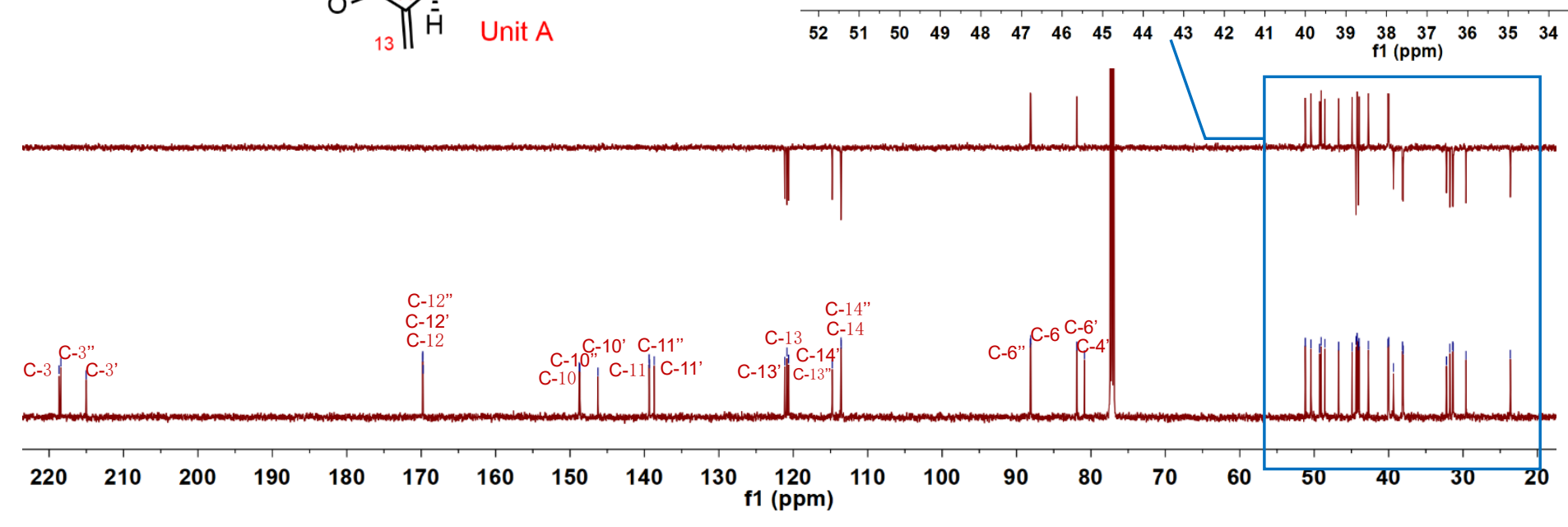

Fig. S17. ${ }^{13} \mathrm{C}\left\{{ }^{1} \mathrm{H}\right\}$ NMR spectrum of compound 2 in $\mathrm{CDCl}_{3}(150 \mathrm{MHz})$. 


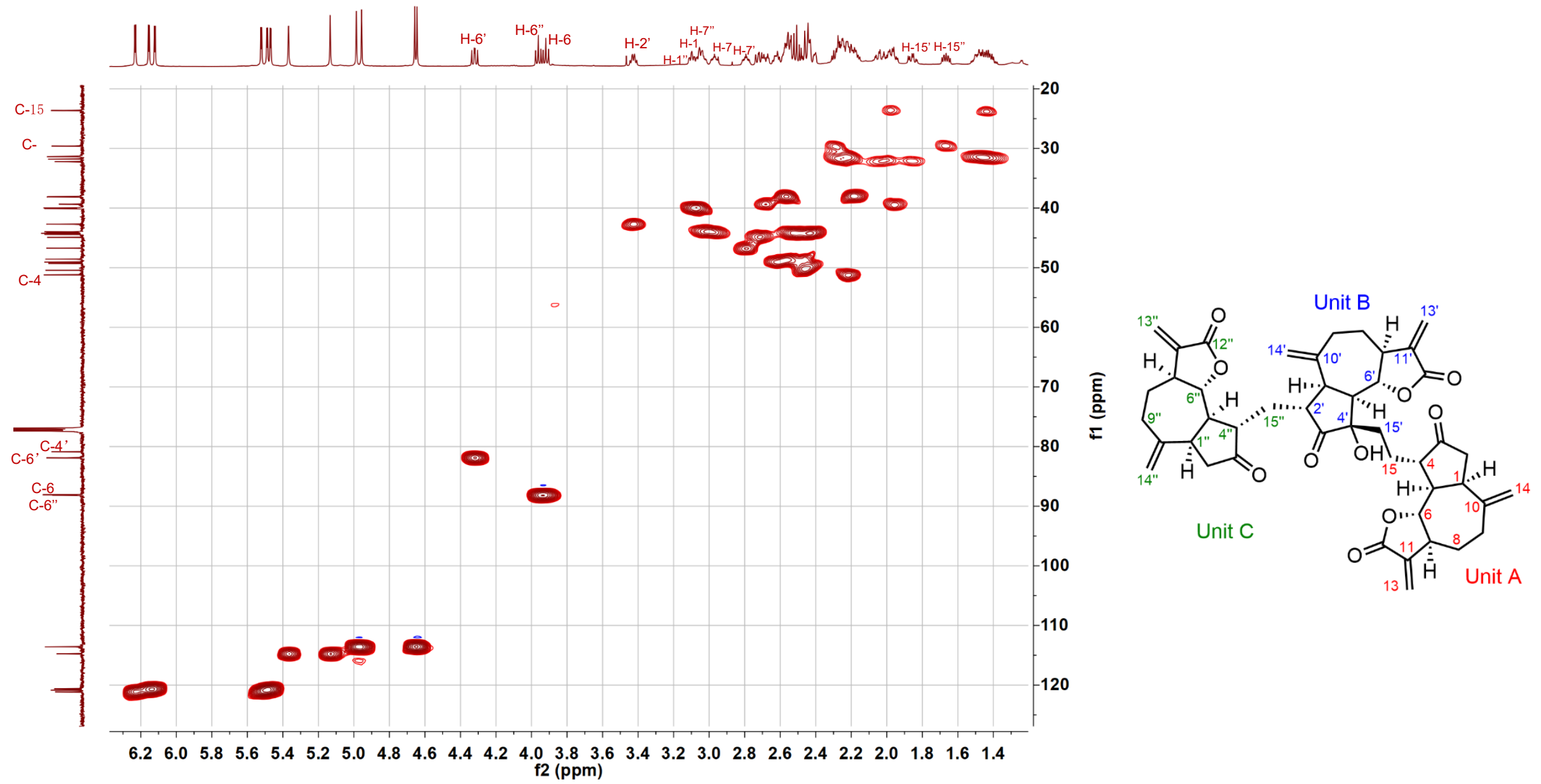

Fig. S18. HSQC spectrum of compound 2 in $\mathrm{CDCl}_{3}(600 \mathrm{MHz})$. 


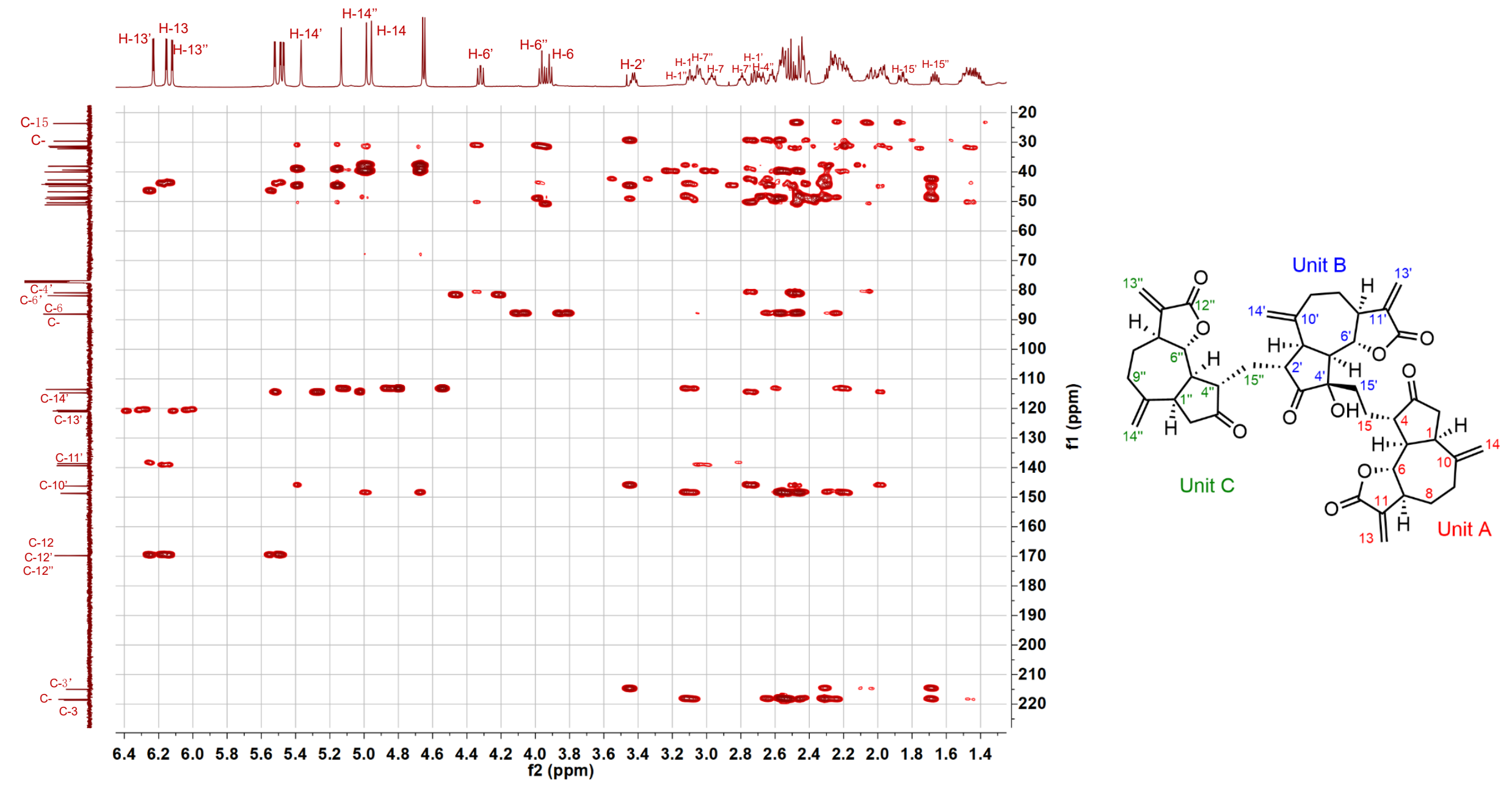

Fig. S19. HMBC spectrum of compound 2 in $\mathrm{CDCl}_{3}(600 \mathrm{MHz})$. 


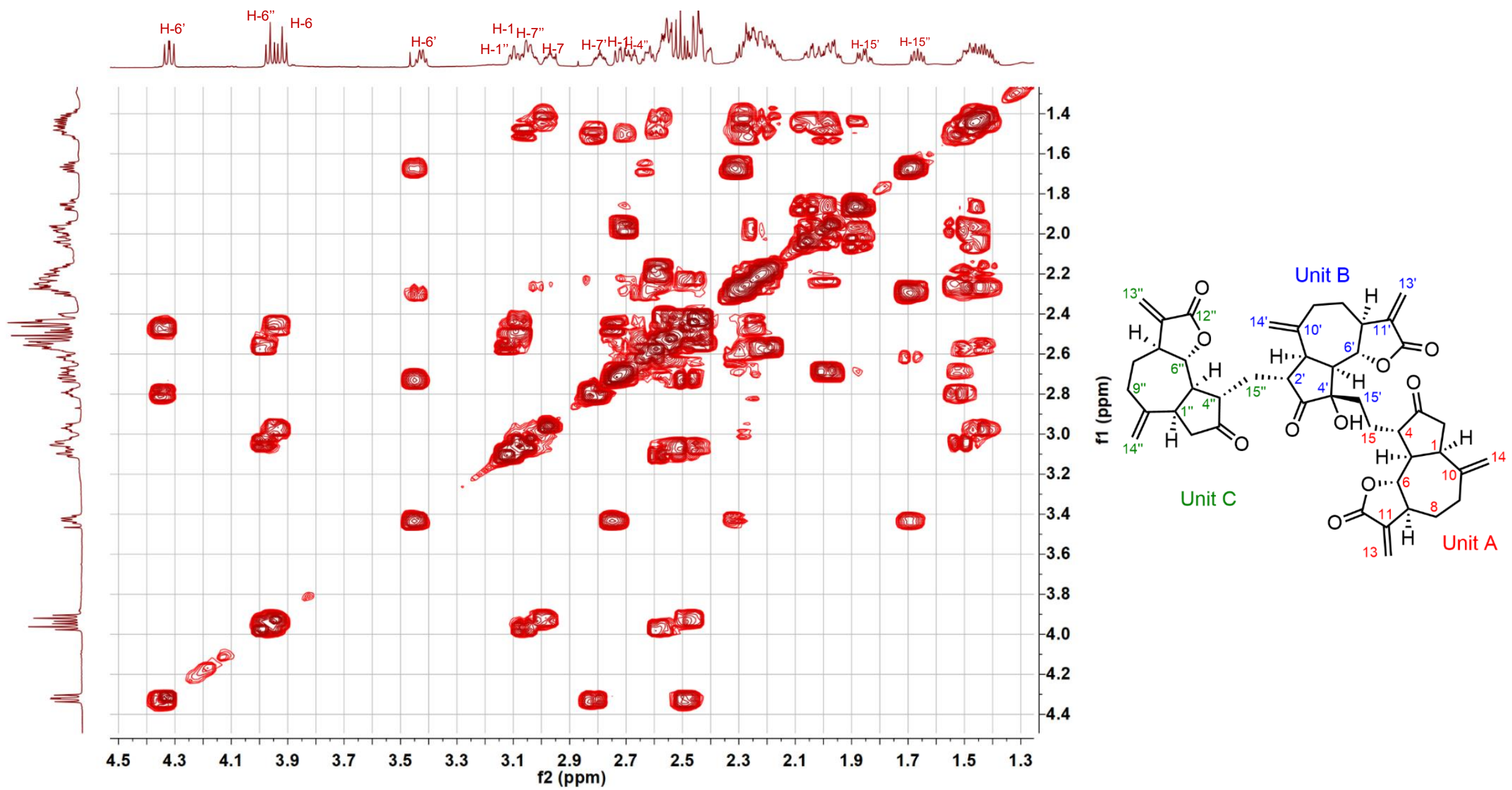

Fig. S20. ${ }^{1} \mathrm{H}-{ }^{1} \mathrm{H}$ COSY spectrum of compound 2 in $\mathrm{CDCl}_{3}(600 \mathrm{MHz})$. 


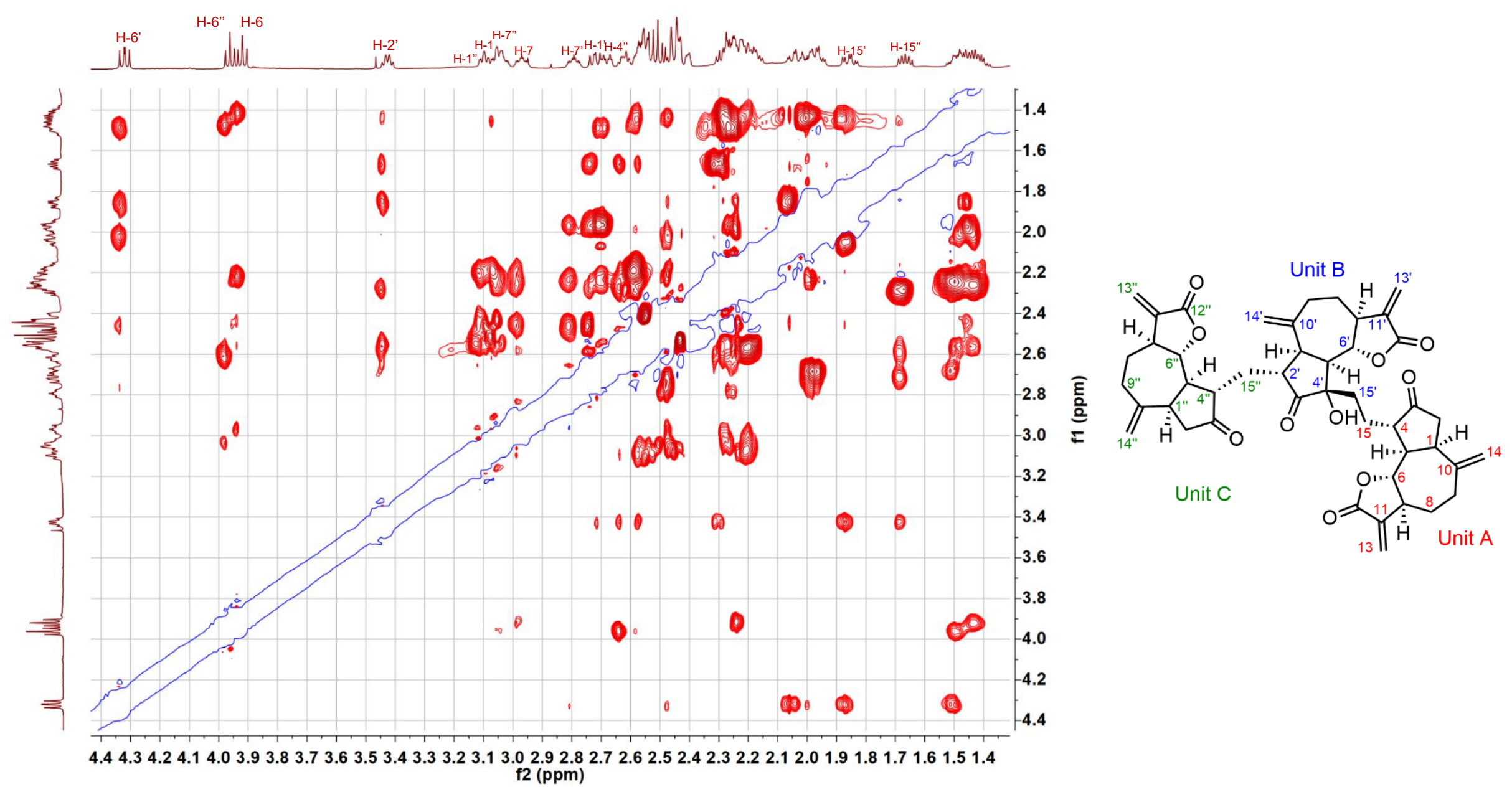

Fig. S21. ROESY spectrum of compound 2 in $\mathrm{CDCl}_{3}(600 \mathrm{MHz})$. 


\section{Experimental details for TDDFT ECD calculations}

The TDDFT ECD calculations for compounds 1-2 were performed using the Gaussian 16 program. ${ }^{1}$ The conformational searching was conducted by the Conflex 8.0 software using the MMFF force field within an energy window of $5.0 \mathrm{kcal} / \mathrm{mol}^{2}$ Conformers within $5.0 \mathrm{kcal} / \mathrm{mol}$ of the lowest energy conformers were stored. The conformers with a molecular mechanic potential energy below $15 \mathrm{~kJ} / \mathrm{mol}$ were subjected for optimization at the level of M06-2X/6-311g(d,p) with the SMD solvent model for methanol (26 conformers for $\mathbf{1}$, and 18 conformers for 2 ). ${ }^{3}$ TDDFT ECD calculations were run at the M06-2X/def2TZVP level with the SMD solvent model for methanol for all optimized conformers with Boltzmann weight above 1.0\%. Calculated ECD spectra were generated using the SpecDis Version 1.71 with suitable sigma/gamma (eV) gaussian broadening ( 0.6 for $\mathbf{1}$, and 0.5 for 2 ) after UV correction $(+30 \mathrm{~nm}$ for $\mathbf{1}$, and $+5 \mathrm{~nm}$ for $\mathbf{2}){ }^{4,5}$

\section{References}

(1) Gaussian 16 [computer program], Gaussian Inc., Wallingford CT, 2016.

(2) CONFLEX 8.0 [computer program], CONFLEX Corporation, Tokyo, Japan, 2017.

(3) Wu, J.; Lorenzo, P.; Zhong, S. Ali, M.; Butts, C. P.; Myers, E. L.; Aggarwal, V. K. Synergy of synthesis, computation and NMR reveals correct baulamycin structures. Nature. 2017, 547, 436-440.

(4) Bruhn, T.; Schaumlöffel, A.; Hemberger, Y.; Bringmann, G. SpecDis: Quantifying the comparison of calculated and experimental electronic circular dichroism spectra. Chirality. 2013, 25, 243-249.

(5) Pescitelli, G.; Bruhn, T. Good computational practice in the assignment of absolute configurations by TDDFT calculations of ECD spectra. Chirality. 2016, 28, 466- 
474.

\section{Bioactivity Assay}

PTP1B Assay. PTP1B enzymatic reaction was carried out as described previously. ${ }^{6}$ The reaction was performed in a $100 \mu \mathrm{L}$ buffer solution [ $1 \mathrm{mM}$ bovine serum albumin (BSA), $50 \mathrm{mM}$ 3-(N-morpholino)-propanesulfonic acid, $1 \mathrm{mM}$ dithiothreitol, and $1 \mathrm{mM}$ ethylenediaminetetraacetic acid (EDTA), $\mathrm{pH}$ 6.5] containing $15 \mathrm{nM}$ human recombinant PTP1B enzyme (Sigma-Aldrich, St. Louis, MO, USA) in 96-well plates. After added compound $\mathbf{1}$, compound $\mathbf{2}$ or oleanolic acid into the designated wells, the plate was pre-incubated at $37{ }^{\circ} \mathrm{C}$ for $30 \mathrm{~min}$. Subsequently, $10 \mathrm{mM}$ pNPP (SigmaAldrich) was added to each well, and the plate was further incubated at $37{ }^{\circ} \mathrm{C}$ for 45 min. Finally, $50 \mu \mathrm{L} \mathrm{NaOH}(3 \mathrm{M})$ was added to each well to stop reaction. The absorbance at $405 \mathrm{~nm}$ was detected using SpectraMax M5 microplate reader (Molecular Devices, CA, USA), and the slope of the initial rate of the kinetic curve in each well was applied to determine the activity of PTP1B. The PTP1B inhibitory ratio was calculated as: $\left(\mathrm{A}_{\text {negative }}-\mathrm{A}_{\text {sample }}\right) /\left(\mathrm{A}_{\text {negative }}-\mathrm{A}_{\text {blank }}\right) \times 100 \%$. $\mathrm{A}_{\text {negative }}, \mathrm{A}_{\text {sample }}$ and $\mathrm{A}_{\text {blank }}$ were absorbance for negative control (only DMSO, pNPP and enzyme), sample and blank control (only DMSO and pNPP), respectively. To determine the PTP1B enzyme kinetic pattern, the absorbance was recorded every 5 minutes for a half hour. The Dixon plot experiment was performed with various concentrations of p-NPP, and the Lineweaver-Burk plot experiment was performed with various concentrations of compound 2 and oleanolic acid. The $K \mathrm{i}$ value was obtained from the interpretation of 
Dixon plots.

Cell Culture. Murine derived C2C12 myoblasts were obtained from American Type Culture Collection (Manassas, VA, USA) and maintained in DMEM (Gibco, Waltham, MA, USA) with $10 \%$ FBS and $1 \%$ penicillin-streptomycin $(\mathrm{P} / \mathrm{S})$ in a humidified incubator with $5 \% \mathrm{CO}_{2}$ at $37^{\circ} \mathrm{C}$. When reach $70-80 \%$ confluence, cells were stimulated to differentiation with DMEM containing 2\% heat-inactivated horse serum (Gibco) for 4-5 days. Media were changed every other day.

Cell Viability. The fully differentiated $\mathrm{C} 2 \mathrm{C} 12$ myotubes were treated with different concentrations of compound 2 for $24 \mathrm{~h}$. DMSO was used as a blank control. Then cells were incubated with DMEM containing $1 \mathrm{mg} / \mathrm{mL}$ MTT for additional 4 h. $100 \mu \mathrm{L}$ DMSO was added to each well to dissolve the formazan crystals. The absorbance at $570 \mathrm{~nm}$ was recorded by a SpectraMax M5 microplate reader. The cell viability was calculated as described previously. ${ }^{7}$

Insulin Stimulated Glucose Uptake. C2C12 myotubes were treated with different concentrations of compound 2 for $24 \mathrm{~h}$. After washed with Krebs-Ringer's phosphate (KRP) buffer (137 mM NaCl, 20 mM HEPES, $4.7 \mathrm{mM} \mathrm{KCl,} 1.2 \mathrm{mM} \mathrm{KH}_{2} \mathrm{PO}_{4}, 1.2 \mathrm{mM}$ $\mathrm{MgSO}_{4}, 2 \mathrm{mM}$ pyruvate and $2.5 \mathrm{mM} \mathrm{CaCl}_{2}, \mathrm{pH}$ 7.4) twice, the cells were incubated in KRP buffer containing $0.2 \%$ BSA for $3 \mathrm{~h}$. Subsequently, the cells were stimulated with insulin $(0.1 \mu \mathrm{M}$ in KRP buffer) for $30 \mathrm{~min}$. After washed with KRP buffer once, the cells were incubated in 2-NBDG solution [2-(N-(7-nitrobenz-2-oxa-1,3-diazol-4-yl) amino)-2-deoxyglucose, Sigma-Aldrich, $100 \mu \mathrm{M}$ in KRP buffer] for $30 \mathrm{~min}$. The intracellular content of 2-NBDG was recorded by a fluorescence spectrometer 
(excitation wavelength: $475 \mathrm{~nm}$; emission wavelength: $550 \mathrm{~nm}$ ). The fluorescence intensity was further normalized by protein content.

Western Blotting Analysis. Western blotting analysis was performed as described previously. ${ }^{8,9}$ Equal amounts of proteins $(30 \mu \mathrm{g})$ were separated by SDS-PAGE (sodium dodecyl sulphate-polyacrylamide gel electrophoresis), and transferred to polyvinylidene fluoride (PVDF) membranes (Bio-Rad, Hercules, CA, USA). After blocking with $5 \%$ nonfat milk for $1 \mathrm{~h}$ at room temperature, the membranes were probed with specific primary antibodies overnight at $4{ }^{\circ} \mathrm{C}$ and then probed with corresponding secondary antibody for $2 \mathrm{~h}$ at room temperature. The immune-blotting signals were developed using a SuperSignal West Femto Maximum Sensitivity Substrate kit (Thermo Fisher), and visualized using the ChemiDoc MP Imaging System (Bio-Rad).

Statistical Analysis. All data were expressed as mean \pm SD based on at least three independent experiments and analysed by Graphpad Prism 6 (GraphPad, San Diego, CA, USA). One-way ANOVA was used for statistical comparison, and $P$-values less than 0.05 were considered statistically significant.

\section{References}

(6) Xu, Y.; Feng, Z.; Zhang, T.; Lv, P.; Cao, J.; Li, D.; Peng, C.; Lin, L. Pimarane diterpenoids from the seeds of Caesalpinia minax as PTP1B inhibitors and insulin sensitizers. Molecules 2020, 25, 4674-4682.

(7) Li, D.; Liu, Q.; Sun, W.; Chen, X.; Wang, Y.; Sun, Y.; Lin, L. 1,3,6,7-Tetrahydroxy8-prenylxanthone ameliorates inflammatory responses resulting from the paracrine interaction of adipocytes and macrophages. Br. J. Pharmacol. 2018, 175, 15901606. 
(8) Zhang, T.; Fang, Z.; Linghu, K. G.; Liu, J.; Gan, L.; Lin, L. Small molecule driven SIRT3 - autophagy - mediated NLRP3 inflammasome inhibition ameliorates inflammatory crosstalk between macrophages and adipocytes. Br. $J$. Pharmacol. 2020, 177, 4645-4665.

(9) Zhang, T.; Liu, J.; Shen, S.; Tong, Q.; Ma, X.; Lin, L. SIRT3 promotes lipophagy and chaperon-mediated autophagy to protect hepatocytes against lipotoxicity. Cell Death Differ. 2020, 27, 329-344 